\title{
Tiberius and the Romanization of the Vasconia - Continuity and change in the early Principate based on a Tiberian coin type from Calagurris
}

Tiberio y la Romanización de la Vasconia - Continuidad y cambio en el Principado basado en un tipo de moneda del reino de Tiberio de Calagurris

TIMO KLÄR

University of Greifswald, Germany I

Saarland University, Saarbrücken, Germany

E-mail: timo.klaer@mx.uni-saarland.de

Orcid ID: https://orcid.org/0000-0002-0663-805 I
RECIBIDO: I I DE JULIO DE 202 I ACEPTADO: 2 DE AGOSTO DE 2021
Abstract: This paper intends to approach a study about the ongoing process of Romanization during the period of government of Tiberius by means of a provincial coin emission from Calagurris in the territory of the Vasconians. To achieve this objective we present an analysis of important elements shown on the coin: the imperial title on the obverse, the iconography and the two duoviri mentioned on the reverse.

Keywords:Romanization; Calagurris; Tiberian reign; Numismatics; Roman-Vasconian identity
Resumen: El presente trabajo pretende estudiar el proceso de romanización durante el gobierno de Tiberio mediante una emisión de moneda provincial de Calagurris en el territorio de los vascones. Para ello, presentamos un análisis acerca de los elementos importantes que se muestran en la moneda: el título imperial en el anverso, la iconografía y los dos duoviri mencionados en el reverso.

Palabras Clave: Romanización; Calagurris; imperio de Tiberio; numismática; identidad romana-vascona. 


\section{INTRODUCTION}

S CHOLARS have dated a coin emission of Tiberius from Calagurris in the Vasconia $^{1}$ to his reign from AD 14-37 and identified it as Tiberius' first emission, i.e. the 18th of the mint of Calagurris. ${ }^{2}$ The coin type has the denomination of an as, in our case (Figure 1) with a diameter of $25 \mathrm{~mm}$, a weight of $11.64 \mathrm{~g}$ and an orientation of $12 \mathrm{~h}$. The obverse shows a laureate head of Tiberius to the right with the inscription TI AVGVS DIVI AVGVSTI F IMP CAESAR. The reverse features a bull standing to the right with his head facing and the inscription L FVL SPARSO, L SATVRNINO, II VIR on right and $\mathrm{M}[\mathrm{C} \mathrm{I}]$ on left. ${ }^{3}$

This paper discusses primarily the historical significance of the visual elements, i.e. the image and the inscription of this coin type (RPC 448), whereas other aspects characteristic of the issue such as for example the choice of the denomination, the origin of the metal and the circulation of the coins with the iconography of a bull will not be discussed here. The focus lies only on Calagurris, other Vasconian cities, like for example Graccurris, will not be discussed here, even though similarities are to be assumed in terms of the iconography of the bull under Tiberian rule. ${ }^{4}$

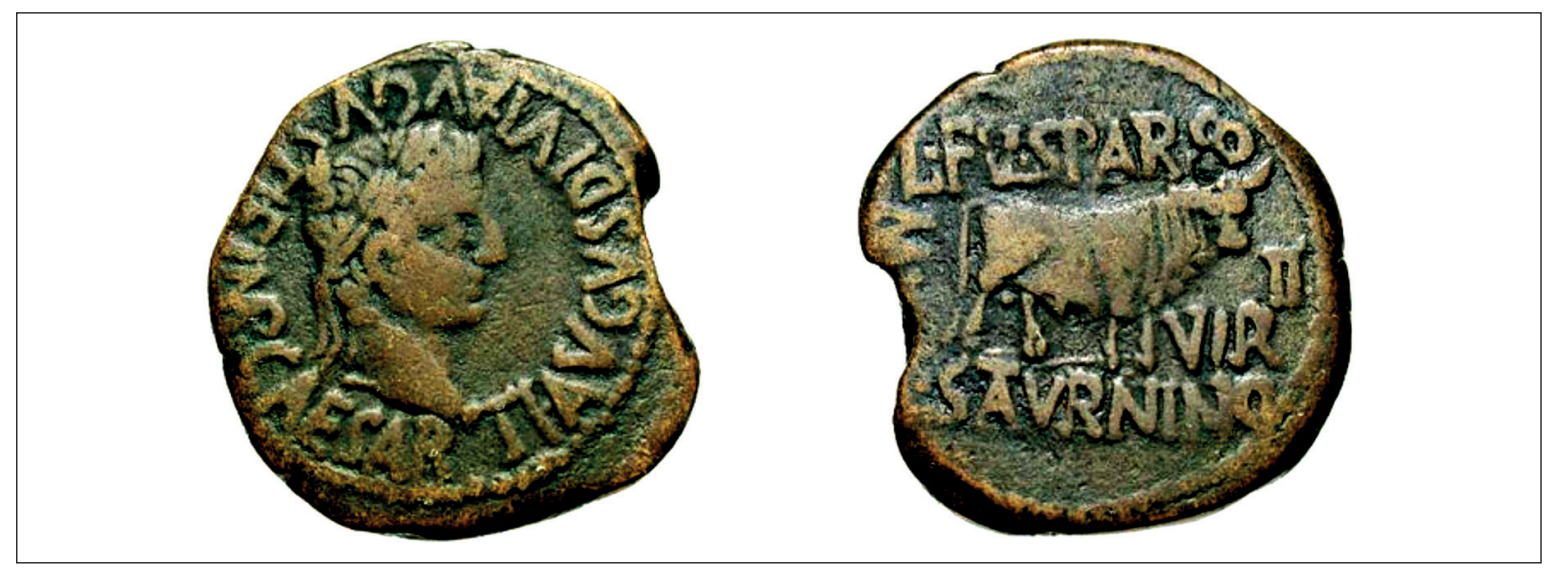

Figure 1

As from Calagurris (RPC 448; SNG Copenhagen 585; de Guadán 1980, 172, 692 and 693; VAuctionsTriskeles 326, 247). John C. Lavender of VAuctions Triskeles

1 Recent scientific research identified not only Calagurris as a Vasconian city but also as a Vasconian mint: (Collado Cenzano, 2006; Beltrán Lloris; Velaza Frías, 2009). Earlier research had suggested a Beronian origin of the native coinage: (García-Bellido, 1997).

2 (Espinosa, 1984: 98; García-Bellido; Blázquez, 2002: 225; Grant, 1950: 36 adn. 143). Grant suggests on iconographical considerations a late, or fairly late date for a number of municipal issues of Ilici, Osca, Calagurris, Graccurris and Cascantum: (Grant, 1950: 140-141):" [...] eight municipia appear to have issued coinage under Tiberius and only five in the last years of Augustus. It cannot, therefore, be concluded that any diminution of municipal mints started at the accession of Tiberius, any more than a diminution of colonial mints; nor is any diminution noticeable during his reign, in which a number of municipal issues are late [Grant's italics].

${ }^{3}$ For the two types of the coins: one with a bull standing in its entirety and another with a head of a bull: (Gozalbes, 2020: 55).

${ }^{4}$ For a detailed discussion of the diffusion of the bull's image under Tiberius in the middle valley of the Ebro: (Gozalbes, 2020). 
The omission of the praenomen imperatoris, created by Tiberius' predecessor Octavian/Augustus, on the obverse legend requires some remarks. Interestingly, the praenomen imperatoris seems to be missing not only on other Tiberian coins from Calagurris and Hispania ${ }^{5}$, but also the second emperor seemed to abstain from its use entirely; however the official title of the second princeps was Imperator Tiberius Caesar Augustus. ${ }^{6}$
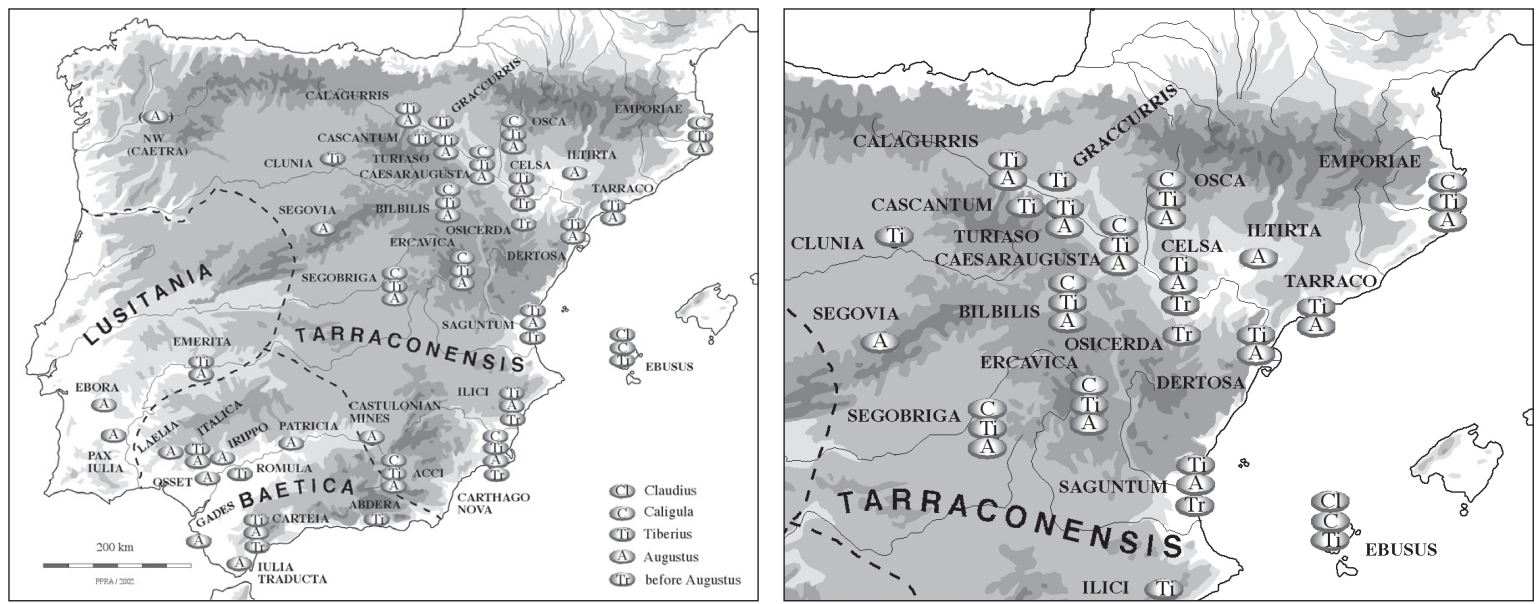

Map of Roman Mints in Hispania (left); Detail of the Mints in Northern Hispania (right).

Pere Pau Ripollès

The reverse of the coin illustrates one moment of the progressive Romanization of the municipium Calagurritanum with the iconography of the bull and the names of the duoviri. Especially the bull is quite common in the iconography of coins in the Early Principate, which has stimulated an ongoing and controversial debate on his iconographic symbolism. On the one hand, research found common ground in a civic and religious interpretation of it in general. On the other hand, the bull could be

\footnotetext{
Missing praenomen imperatoris on coins from Calagurris: (García-Bellido; Blázquez, 2002: 225, No. 22-25 (Tiberian coins: emissions 18-20); Grant, 1950: 46-47; Hill, 1931: 170). Grant mentions only one single irregular coin-title at Calagurris with the praenomen imperatoris: IMP CAESAR TI AVGVS DIVI AVGVSTI F. Missing praenomen imperatoris on coins from Hispania: (García-Bellido; Blázquez, 2002: 18, No. 7-8 (Abdera); 20, No. 5-8 (Acci); 45, No. 61-64 (Sagunt); 66, No. 17-21 (Bilbilis); 75-79, No. 23-50 (Caesaraugusta); 100, No. 33-37 (Carthago Nova); 119, No. 70 (Ebusus); 125-127, No. 42-50 (Emerita Augusta); 142-143, No. 5-6 (Ercavica); 153-154, No. 71-80 (Gades); 155, No. 1-2 (Graccurris; also a Vasconian city and also a bull on the reverse); 176, No. 3 (Ilercavonia); 180-181, No. 7-12 (Ilici); 214-215, No. 5-6 (Italica: No. 5 has IMP TI CAESAR AVGVSTVS PON MAX; no. 6 has TI CAESAR AVGVSTVS PONT MAX IMP); 219-220, No. 5-8 (Cascantum); 240, No. 36-37 (Celsa); 310, No. 24-31 (Osca); 341, No. 9-10 (Segovia); 364-365, No. 17-25 (Tarraco); 380-382, No. 38-46 (Turiaso; no. 41-43 with bull on the reverse); 399, No. 1-3 (Osicerda; no. 2 with bull on the reverse).

6 Suet. Tib. 26,2; Cass. Dio 57,2,1; 57,8,1-2; 59,3,2. Missing praenomen imperatoris on imperial coins: RIC I2 Tiberius 93-101, s.v. obverse legends; BMC I Tiberius 120-145, No. 1-177. On inscriptions: e.g. CIL II 1660 (=ILS 161); CIL VI 930 (=ILS 244). BMC I, LXVI-LXVII:“What is certain is that Augustus used 'imperator' as a praenomen, suppressing his own praenomen ' $C$. (Gaius)', while Tiberius, Caligula and Claudius abstained from its use entirely." For the official titles: PIR II2 C 941, 224-225; (Hammond, 1957: 22 with note 5; Kienast; Eck; Heil, 2017: 71).
} 
interpreted in Hispania locally different, i.e. its meaning could vary from one region or micro-region to another quite significantly. ${ }^{7}$ The coin emission therefore could give an insight into the administrative structures of the Hispanic north in the first decades of the early Roman Empire by means of the imperial title, the Romanization of Calagurris and the two duoviri mentioned on the reverse: L. Fulvius Sparsus and L. Saturninus. In the following chapters I will elaborate the significance of the coin type further.

\section{THE OBVERSE: REMARKS ON THE IMPERIAL TITLE OF TIBERIUS}

On 19 August AD 14, the first Roman princeps Augustus died in Campo Nola. The adoption of Tiberius in June AD 4 had made him the successor of Augustus; since then he was called Tiberius Iulius Caesar. ${ }^{8}$ The name of Augustus was, probably on 17 September AD 14, transferred to Tiberius, whose full name was now Tiberius Caesar Augustus, also an indication of the transition of power. ${ }^{9}$ Since the winter of 40/39 BC, shortly after the pax Brundisina, Octavian had begun to use the imperatorial title as his praenomen, ${ }^{10}$ in addition to the patronym Divi (Iuli) f(ilius) and the imperatorial acclamation:

"[He personally monopolized] the title of victorious Roman generals to an extent that had not occurred before. Simultaneously, the title was no longer linked to specific achievements, i.e. victories, which raised Octavian victorious quality to an absolute height and perpetuated it limitlessly. The new Imperator Caesar emphasized his claim to being the ultimate and unsurmountable victor."11

7 (Gozalbes, 2020: 41-44) with further literature and recent research on the subject.

8 FAmit June 27; Vell. Pat. 2,103,3 (27 June). (Scheid; Broise, 1980: 234; Bernecker, 1980: 16; Kienast; Eck; Heil, 2017: 71).

9 On the events surrounding the transition of power: Tac. Ann. 1,7-52; Vell. Pat. 2,123-125; Cass. Dio 56,31-47; Suet. Tib. 22-26; (Timpe, 1962: 48-56; Sage, 1982/1983). For the 17 September as dies imperii: (Fabia, 1909; Hohl, 1933; Schmitt, 1958; Kampff, 1963; Goodyear, 1972: 169-176; Flach, 1973). Beginning of September: (Wellesley, 1967; Schrömbges, 1986: 65-92). For a later date in October: (Pippidi, 1944: 125-132; Béranger, 1953: 7-24; Klingner, 1954: 26-37; Grenade, 1961: 394-443; Levick, 1976: 68-81). For the name: (Kienast; Eck; Heil, 2017: 71).

${ }^{10}$ On the assumption of the praenomen imperatoris by Octavian: (McFayden, 1920; Syme, 1958a; Lesuisse, 1961; Deininger, 1972: 994-995; Eck, 2006: 49; Havener, 2016: 9-34). For the date: Sydenham, 1952: 207, no. 1329; 1331; IAph 2007, 8,25-26; 30-32 (39/38 B. C.); (Syme, 1958a: 179-182; Kienast, 1961: 403; 419-420; Stäcker, 2003: 426; Dahlheim, 2010: 191; Levick, 2010: 37). 40 BC: (Combès, 1966: 132-135; Schumacher, 1985: 203-205) with the reference to RRC 534,1: Ov: IMP DIVI IVLI F TER IIIVIR R P C. The coin marks the transition to the praenomen imperatoris: (Kienast, 2009: 48; Assenmaker, 2012: 139; Galinsky, 2012: 38; Havener, 2016: 16; 68; Kienast; Eck; Heil, 2017: 32).

${ }^{11}$ (Havener, 2016: 13): "[...] [Er personalisierte] den Titel der siegreichen römischen Feldherren in einem Maße, wie dies bis zu diesem Zeitpunkt noch nicht vorgekommen war. Zugleich wurde der Titel auf diese Weise von der Bindung an spezifische Leistungen, d.h. Siege, befreit und damit die Sieghaftigkeit Octavians gleichsam verabsolutiert und unbegrenzt perpetuiert. Der neue Imperator Caesar machte seinen Anspruch deutlich, als ultimativer und unübertrefflicher Sieger aufzutreten." [My translation; Havener's italics]. (Syme, 1958a: 181):"The wider connotations of 'imperator' being admitted, it will appear plausible that the praenomen 'Imperator' embodies and advertises the peculiar claim of Octavianus to be the military leader par excellence." (Grant, 1950: 46-47). 
In doing so, Octavian had created an innovation. He had to defend himself against his rivals during the triumviral period and with this title he was able to emphasize not only the special affinity to the soldiers, but also the renewal of Rome, and therefore could use it in the public life of Rome. The military reference of the imperatorial title was important, because it lifted him over the other generals who could also call themselves imperator. ${ }^{12}$ Tiberius however, unlike his predecessor, declined the praenomen imperatoris and also the title of pater patriae. ${ }^{13}$ This was surprising because the princeps as commander-in-chief had to prove his victoriousness over and over again; in that he was responsible for the prosperity and achievements of the res publica. What, therefore, could be more fitting than an unlimited perpetuation of the imperatorial title by taking it as a praenomen? The imperatorial acclamation, open in principle to all generals, was thus turned into an element of imperial nomenclature by Augustus. Why then did Tiberius decline the honours for the princeps and endangered the newly established system of power? After all, the military was one of three important pillars of the Principate. ${ }^{14}$

A look at the development of the imperatorial title during the Roman Republic should shed some light on the matter. Cassius Dio mentions that Caesar was already granted the use of the praenomen imperatoris in $45 \mathrm{BC}$. This is doubtful. ${ }^{15}$ In the Republican period, a victorious general who had been acclaimed by his troops as imperator, was allowed to carry the title only until the day of his triumph. The magistrate had to wait outside the pomerium with his troops until a decision was made by the senate whether he would be awarded a triumph. Sometimes, this took so much time that a cancellation of a triumph could occur: In this case the general remained in possession of his command. ${ }^{16}$ One could assume that the imperatorial title was initially used exclusively to sample out temporarily a magistrate of the Late Republic.

There is evidence for a further development of the imperatorial/imperial title, on the basis of Caesar's titles since the beginning of 45 BC. A dedication from Curubis in Africa Proconsularis carries the inscription C. Caesare imp. cos. IIII, L. Pomponius L. l. Malcio duovir V murum oppidi totum ex saxo quadrato aedific. coer. and a senatorial

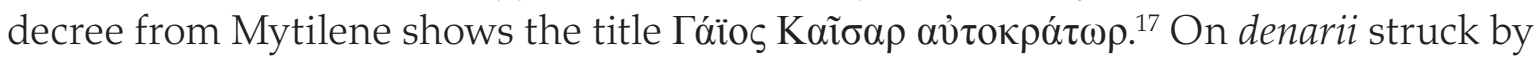

\footnotetext{
12 (Kienast, 1961: 420; Campbell, 1984: 93-96; Stäcker, 2003: 428-439; Havener, 2016: 14-15).

${ }^{13}$ Suet. Tib. 26,2; Cass. Dio 57,8,1; Tac. Ann. 1,72,1; 2,87. BMC, LXVII.

14 (Flaig, 1992).

${ }^{15}$ Cass. Dio 43,44,2; Suet. Iul. 76,1; (Syme, 1958a: 176-179; Kienast, 1961: 417-418; Combès, 1966: 123-130; Deininger, 1972: 991-993; Stäcker, 2003: 427-428; Havener, 2016: 12).

${ }^{16}$ Cicero acclamation in October 51 BC: Cic. Att. 5,20,3; see. Cic. Att. 10,11,5. Since January 4, 49 BC he waited outside the pomerium for a triumph: Cic. Fam. 2,12,3; 15,5,2; Cic. Att. 6,8,5; 7,1,5; 7,1,7; 7, 2,6; 7,3,2; 7,4,2; 7,3-4; Plut.Vit. Cic. 37. He left Italy in June 49 BC without having celebrated the triumph: Cic. Fam. 16,11,3; 16,12,5; 14,7; Cic. Att. 7,11,5; 7,14,2; 7,15,2; 9,18-10,18; Plut.Vit. Cic. 38; Cass. Dio $41,18,4$. ILS 877; 890, where it is also noticeable for Late Republican times that an ordinal number does not have to follow the title.

${ }^{17}$ Curubis: Dessau, ILS 5320. Mytilene: Syll. ${ }^{3}$ 764, 10-11; (Kienast, 1961: 417).
} 
the monetales M. Mettius, P. Sepullius Macer and C. Aemilius Buca roughly a month before Caesar's death, the legends include CAESAR IMPER, CAESAR IMP and CAESAR IM P M. Here the imperatorial title could be understood as a cognomen and not as praenomen imperatoris, as it is assumed by Cassius Dio. It is possible that Cassius Dio confuses the praenomen imperatoris for Caesar with the honour to carry the imperatorial title permanently, which was granted by the senate in October 45 BC, contrary to tradition. Caesar appears on the obverse of the said types with a golden royal wreath, which suggests yet another further development, i.e. a monarchical understanding of his role. ${ }^{18}$ Thus, it was only a little step from the permanent imperatorial title, interpreted as cognomen, to the interpretation as a praenomen by Octavian and hence the creation of the praenomen imperatoris. ${ }^{19}$

Since Tiberius, as the heir of Augustus, had the convenient option to also adopt the praenomen imperatoris himself. The fact that he not only declined that privilege but also rejected or only reluctantly accepted other honours, led to a new style of rule, which was formative for the principate: "[...] at the level of discourse, [Tiberius] introduced a new style of demonstrative differentiation from Augustus [...]." ${ }^{20}$

Tiberius' official title was Imperator Tiberius Caesar Augustus. According to the ancient sources he rejected this title at the beginning of his reign. Further numismatic and epigraphic evidence shows that the praenomen imperatoris for Tiberius appears only on a very limited quantity of provincial coins from Hispania, and on provincial inscriptions. ${ }^{21}$ Here, it could be argued however, that the exact title of the princeps in the province was not widely known. Though the omission of the praenomen imperatoris on other coins from Hispania is striking, ${ }^{22}$ it is far more plausible to suggest a

18 (Kraft, 1952/1953: 65-74). For the monarchical understanding of the role of Caesar: (Gelzer, 1921: 252-309; Kroymann, 1970; Gesche, 1976: 142-179; Meier, 1980: 65-96; Meier, 1982: 510-533; Jehne, 1987; Botermann, 1992; Will, 1992: 194-217; Girardet, 1996; Welwei, 1996; Jehne, 1997: 101-114; Morgan, 1997; Dahlheim, 2005: 217-234; Will, 2009: 163-182; especially 174-176; Gardner, 2009 : 57-71; Meier, 2014; Sigmund, 2014: 169-182; Stevenson, 2015: 123-180), with further literature. (Rosenblitt, 2019) for the political culture of the Late Roman Republic. Coins: (Alföldi, 1953: 86).

19 (Syme, 1958a: 177): "[...] a cognomen can be transferred and used as a praenomen."

20 (Havener, 2016: 376): [...] [Tiberius begann] in demonstrativer Abgrenzung zu Augustus [...] auf der Ebene des Diskurses einen neuen Stil einzuführen. [My translation]; (Gotter, 2015: 223-231, especially 230): "What was built up by one (successful) emperor in terms of meeting expectations was constantly undermined by his successor, whether one subtly rejected the achievement of the deceased or went straight for the jugular. [...] Emperors thus became spokesmen of a discourse, which delegitimized the previous emperor and, in the endless repetition of the procedure, propagated tropes showing an anti-monarchic component."

${ }^{21}$ Coins: (García-Bellido; Blazquéz, 2002: 214-215, No. 5-6 Italica): No. 5 has IMP TI CAESAR AVGVSTVS PON MAX; no. 6 has TI CAESAR AVGVSTVS PONT MAX IMP. Grant mentions only one single irregular coin-title at Calagurris with the praenomen imperatoris: IMP CAESAR TI AUGUS DIVI AUGUSTI F: (Grant, 1950: 46-47) with further literature and here note 6. Inscriptions: CIL VIII 685: Romae et imp. Ti. Caesari Augusto sacrum. CIL VIII 10023: Imp. Caes. Augusti f. Augustus.

22 Here, note 6. 
knowledge of Tiberius' rejection of the praenomen imperatoris. This new style can be seen in the legend on the obverse: TI AVGVS DIVI AVGVSTI F IMP CAESAR; it is demonstratively different to its predecessor Augustus. Tiberius used the title imperator certainly not as a praenomen, but one can understand the title as a cognomen, which led Tiberius to link himself with the Late Republican tradition, since Tiberius was acclaimed as imperator several times in the wars he fought under Augustus - more than any other general. With that, Tiberius could refer to his military quality as a leader as well as achieve a differentiation from Augustus. ${ }^{23}$

Coins from Northern Hispania without the praenomen imperatoris of Tiberius and the Bull on the Reverse

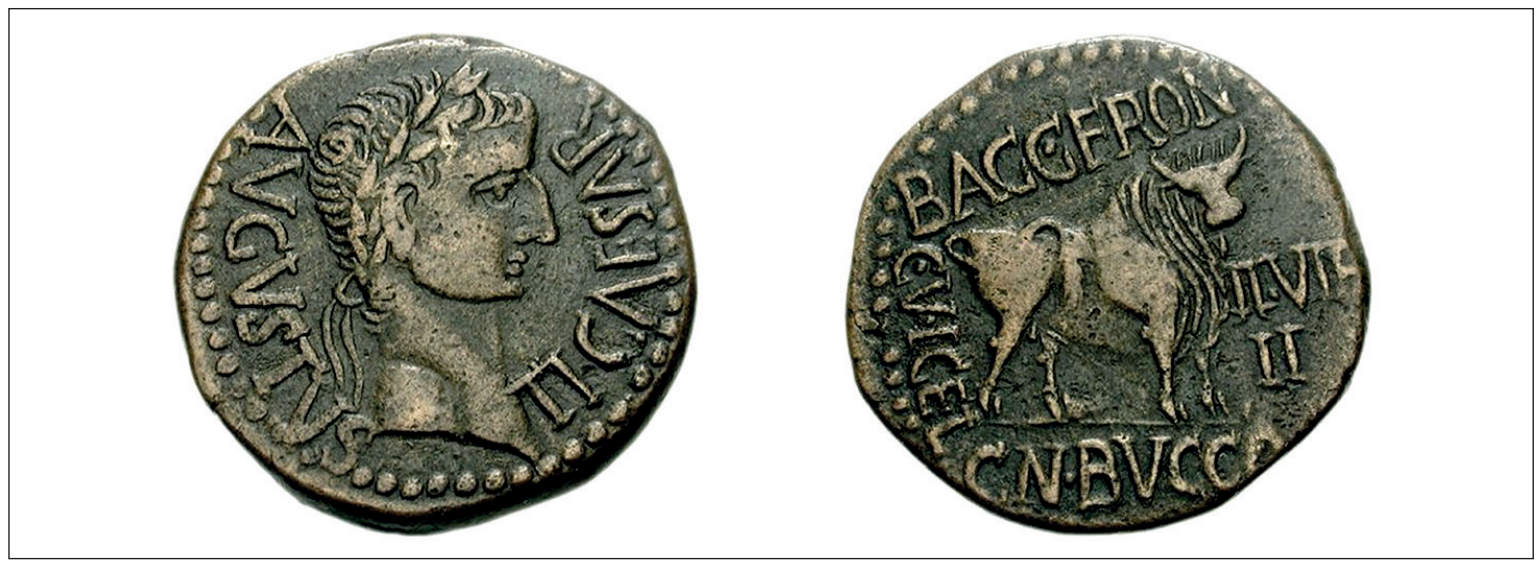

Figure 2

As from Celsa (RPC 279a). Pere Pau Ripollès

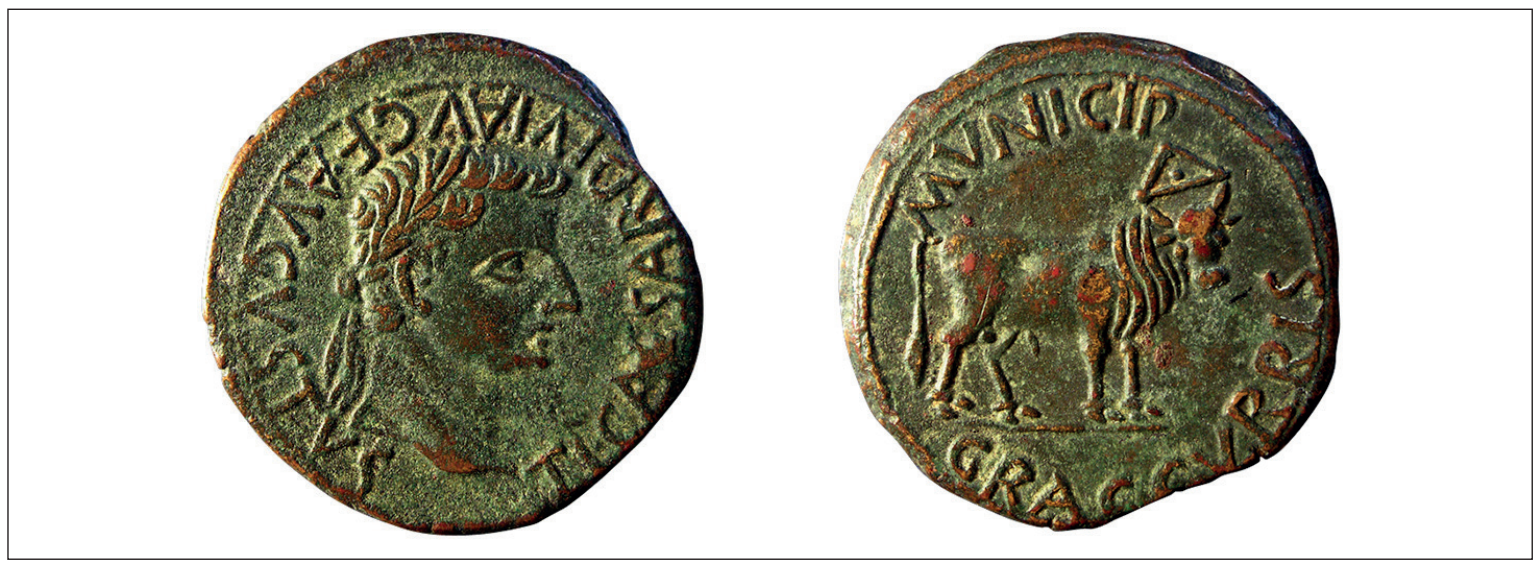

Figure 3

As from Graccurris (RPC 429). Pere Pau Ripollès

${ }^{23}$ Suet. Claud. 12,1. Connection with the Republican tradition: (Campbell, 1984: 94; Grant, 1950: 4748) for the cognomen imperatoris. Imperatorial acclamation: CIL XI 367 (=ILS 113). For this inscription: (Hammond, 1957: 20 with note 3; Horster, 2000: 35). However Tiberius seems to have referred back to his predecessor on coins in his early reign. Augustus is mostly remembered as divus, not as military leader: (Günther, 2014: 57-59). 


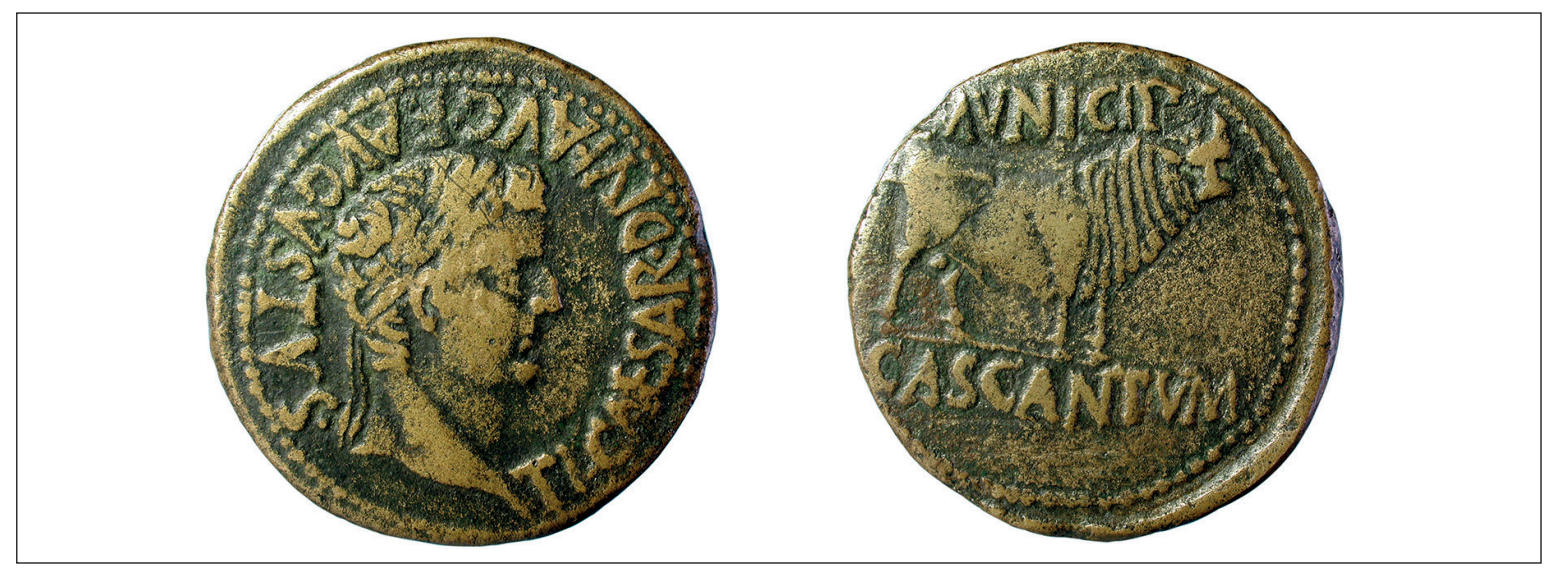

Figure 4

As from Cascantum (RPC 425 NY HSA). Pere Pau Ripollès

\section{THE REVERSE LEGEND:}

\section{THE ROMANIZATION OF THE MUNICIPIUM CALAGURRITANUM}

Calagurris Nassica received municipal status probably in 26 BC. ${ }^{24}$ In that year, Augustus took action in the Cantabrian War against the Cantabrians and Asturians on the Iberian Peninsula. For this purpose he had initially stayed in Tarraco, before moving on to Segisama. He may have stopped in Calagurris to grant municipal rights there. ${ }^{25}$ Regardless, asses and semisses from Calagurris with the obverse legends MVN CAL, MVN CAL IVL, MVN CAL (AG), MVN CAL IVLIA (asses), MV CAL (semisses), M C I, M CAL I and the reverse legend II VIR, which can be dated to the Augustan period, prove a granting of these rights under the first princeps. ${ }^{26}$ The use of the nomen gentile Iulia caused M. Ruiz Trapero to accept the award of municipal status under Caesar, but the evidence is difficult and inconclusive. ${ }^{27}$

In military terms, Calagurris was also important for peacekeeping, because it was close to the battle zones, but as a Vasconian city was not involved. ${ }^{28}$ Shortly thereafter, a mint was founded in Calagurris, which underlines the importance of the city. ${ }^{29}$ Furthermore, the close relationship of the Calagurritans to Octavian/Augustus could have played a role in the granting of the rights. Since the triumviral period, the later princeps had Calagurritans as bodyguards, whom he dismissed shortly after his victory over

${ }^{24}$ (Beltrán Lloris, 2017: 526).

${ }^{25}$ Augustus in Hispania 26 BC: Suet. Aug. 26,3; Flor. 2,33,48; Oros. 6,21,1; (Espinosa, 1984: 73; 83-87). For the date: (Grant, 1946: 165-166). This was already doubted by (Vittinghoff, 1951: 108 with note 4 and Brunt, 1971: 603). Before 27 BC: (Wiegels, 1985: 103).

26 (Hübner, 1893: No. 64a; Hill, 1931: 176-179; Vives, 1924: 96-99). Municipal status: (HernándezVera; Núñez Marcén; Martínez Torrecilla, 2005: 109). Possible verification of the municipal status: ERRioja 5: ---/[---Pio/F]eli[ci In]/vict[o Aug(usto)/pont(ifici) max(imo)/t]ribu[n(icia) pot(estate) ----?/pa]tri p[atriae---/mu]ni[c(ipium) ?---]. (Pascual Mayoral; Pascual González, 1984: 62).

27 (Ruiz Trapero, 1968: 92-93).

28 (Iguácel de la Cruz, 2007). Allegiance between Vasconians and Romans: (Klär, 2017: 49-107).

29 (Espinosa, 1984: 75-83; García-Bellido, 2007). 
Antony at the battle of Actium. ${ }^{30}$ Already, his adoptive father Caesar had Hispanic bodyguards around him, and it is likely that they also included Calagurritans. Augustus had also been able to convince himself on several occasions of their suitability and may have used his journey to Hispania to now express his gratitude for Calagurritan services with the elevation of Calagurris to a municipium Romanorum in 26 BC. ${ }^{31}$ This started the Romanization process of Calagurris, which continued in the Tiberian period. This is clearly evident in the coin to be discussed, as reference is still made to the municipal status (M C I) and moreover, to the duoviri (L FVL SPARSO, L SATVRNINO - II VIR).

While there is hardly any evidence for L. Saturninus, the sources are better for L. Fulvius Sparsus. The Calagurritan gens Fulvia enjoyed a high reputation in the late-Augustan and early-Tiberian periods in Calagurris, as coin findings show. ${ }^{32}$ A C. Fulvius Rutilus is documented as duumvir of the city between 2 BC and 14 AD and could easily have paved the way for our L. Fulvius Sparsus, duumvir in Tiberian times. If one looks at the urban Roman prosopography of this time, one notices that a namesake of the Calagurritan L. Fulvius Sparsus in the Augustan period was a student of M. Porcius Latro, a rhetor or declamator in Rome. ${ }^{33}$ The latter came from Corduba, suggesting that L. Fulvius Sparsus also came from Hispania, as Romans from the same region of provenance preferred to come together. ${ }^{34}$

The princeps had been reorganizing the provinces in Hispania since $27 \mathrm{BC}$. He divided Hispania ulterior into two new provinces: Lusitania and Baetica and Hispania citerior was expanded into the north-west to Gallaecia. Augustus also set up juridical divisions in the Hispanic provinces, i.e. conventus iuridici, for religious, fiscal and political purposes; with these conventus the rural population was forced to go into the cities to perform their duties. Additionally, certain provincial cities received the status as colonia, municipia or civitas vetera, i.e. Roman cities; in these, the local population could cooperate with the Romans in many ways. For example, the local elite assumed office as duovires in the municipia, which lead to a process of Romanization that was essential to a successful integration and administration in Hispania after Augustus. ${ }^{35}$ Thus, it would be obvious to assume a connection from Calagurris to Rome and vice-versa already in the Augustan period. This could have been conducive to the Romanization of Calagurris. ${ }^{36}$

${ }^{30}$ Suet. Aug. 49,1; (Espinosa, 1984: 71).

${ }^{31}$ Suet. Aug. 8,1; Vell. Pat. 2,59,3; Nic. Dam. 10,21-11,25; (Espinosa, 1984: 71-75; Klär, 2017: 106).

32 (Grant, 1946: 166; Espinosa, 1984: 96-97).

${ }^{33}$ Sen. contr. 1,2,2; 1,3,3; 1,3,7; 1,4,3; 1,7,15; 2,5,10; 7,2,3; 7,4,1-2; 7,6,3; 7,6,23; 9,1,7; 9,2,5; 9,3,4; 9,4,3; 9,5,4; 9,6,1; 10 praef. 11-12; 10,1,5; 10,2,4; 10,3,3; 10,4,8-10; 10,4,14; 10,4,23; 10,5,8-10; 10,5,23; 10,5,26. For Lucius Fulvius Sparsus: PIR III 560; (Bornecque, 1902: 167; Münscher, 1910: 279-280).

${ }^{34}$ Origin of Latro: (Helm, 1953: 234; Klär, 2017: 112).

${ }^{35}$ For the administration: (Alföldy, 1969; Alföldy, 2007). Conventus: (Sancho Roger, 1981: 25-33; Dopico Caínzos, 1986; Le Roux, 2004; Alföldy, 2007: 333-338; Klär, 2017: 14-15; 97-100) with further literature and references to the measures under Augustus. For the municipia: (Ortiz de Urbina, 1995). For the local population and the assumption of Roman culture: (Barceló, 1995: 63-64).

${ }^{36}$ (Espinosa, 1984: 98). Importance of the gens in Hispania: (Badian, 1958: 309; Syme, 1958b: 783; Klär, 2017: 111-112). For the coin types in Calagurris in relation to the municipal status: (Klär, 2017: 105-106 with note 44). 


\section{THE ICONOGRAPHY OF THE REVERSE: THE BULL AS REPRESENTATION OF A SYNCRETISM?}

A passage from book three of Strabon's Geographika refers to the Celtiberians and their northern neighbours, the Vasconians, as moon worshippers, who offer sacrifices to a nameless god at full moon. ${ }^{37}$ The deity is not mentioned, but on the basis of archaeological evidence it can be demonstrated that the moon cult was associated with a bull that was worshipped in the Vasconian territory as the deity Lacubegis. Ujué (Navarra) may possibly have been adopted as the centre of the deity, ${ }^{38}$ because there is a bull protome on a side of a votive offering from Ujué which is dedicated to the native god Lacubegis (Figure 5;7). The decoration of the votive offering and the name Lacubegis have led researchers to assign different functions to this god. On the one hand it has been associated with fertility. ${ }^{39}$ On the other hand it was assumed that the name refers to water and it was suggested that the god Lacubegis may be associated with the Rio Aragón and a nearby torrent flowing in the vicinity of Ujué. ${ }^{40}$ Moreover an interpretation as patron god can be found, based on the second part of the name, which means in Basque begi $=$ eye ${ }^{41}$ However, the Basque word behi $=$ bovine fits better as a form of this deity for a moon cult, and is therefore more likely. ${ }^{42}$ The founders of the stone can be determined in their social position. Both Coelius Tesphoros and Coelius Telesinus point to a Greek origin in the cognomina. Thus the founders could be identified as liberti. ${ }^{43}$

Another votive for Iuppiter from Ujué has been discovered, ${ }^{44}$ which has the same benefactors as the Lacubegis votive (Figure 6). Both votives are practically identical, except for the dedication, which can be interpreted as a variation of the formula. Both were probably erected at the same time. Since Iuppiter is often associated with the bull, for example in the myth of Europe ${ }^{45}$, a veneration of Lacubegis as Iuppiter should not be ruled out. ${ }^{46}$ Thus, this may be an indication that the local population understood

\footnotetext{
37 Strabo 3,4,16.

38 (Canto, 1997: 31-40). The bull, which can certainly be found elsewhere in the Ebro valley, is interpreted quite differently by other natives: (García-Bellido; Blázquez, 2002: 221-225; Gonzalbes 2020).

${ }^{39}$ ILER 860; IRMNa 34 with pl. 34 a und b; HEp 7, 2001: 480; HEpOl 457: Coeli(i) Te/sphoros/et Festa/et Telesi/nus Lacu/begi ex/voto. Votive and inscription: (Taracena; Vázquez de Parga, 1946: 465, 59 with pl. 27 and 28; Blázquez, 1962: 176-177 with pl. 38; Gamer, 1974: 243, 39 with pl. 55a; Gamer, 1989: 250, NA 18 with pl. 44c und d; Canto, 1997: 37-38, with 13 und figure 7; Velaza, 2011: 575-576, 3 with figure 1). Name Lacubegis: (Blázquez, 1975: 111-112; Velaza, 1995: 213).

40 (Elorza, 1972: 363; Hernández Guerra 1997, 172, No. 10).

41 (Uranga, 1966: 223; Elorza, 1972: 363; Hernández Guerra, 1997: 172, 10).

42 (Iraburu, 1975: 83-85; Huarte Lerga, 1997: 361-368).

43 (Solin, 1982a: 363-366; Solin, 1982b: 1296; Velaza, 2011: 576).

${ }^{44}$ IRMNa 33 with pl. XXXIII: Coelii/Tespho/ros et/Festa/et Tele/sinus Io/vi sacrum. (Taracena; Vázquez de Parga, 1946: 464, 58c with pl. 26; Gamer, 1974: 243, 40; Iraburu, 1975: 85; Gamer, 1989: 250, NA 19 with pl. 43e; Velaza, 2011: 576, 3 with figure 2).

45 (Cook, 1914: 633-715; Canciani, 1997: 421-470). For the Europe-Bull myth: Ov. met. 2,833-875.

46 (Velaza, 2011: 576-578).
} 
the god Lacubegis as Iuppiter and worshipped him ritually. Another example is an altar for Iuppiter from Aibar, where also a head of a bull appears as decoration, which perhaps also points to an interpretation of the god Lacubegis as Iuppiter. ${ }^{47}$ Therefore, these votive stones are a sign of worship of the local gods in interplay with the Roman deities. If this syncretism was intentional, it is a clear indication of the integration of the Vascons into Roman territory.

\section{Votives from Ujué for Lacubegis and Iuppiter}

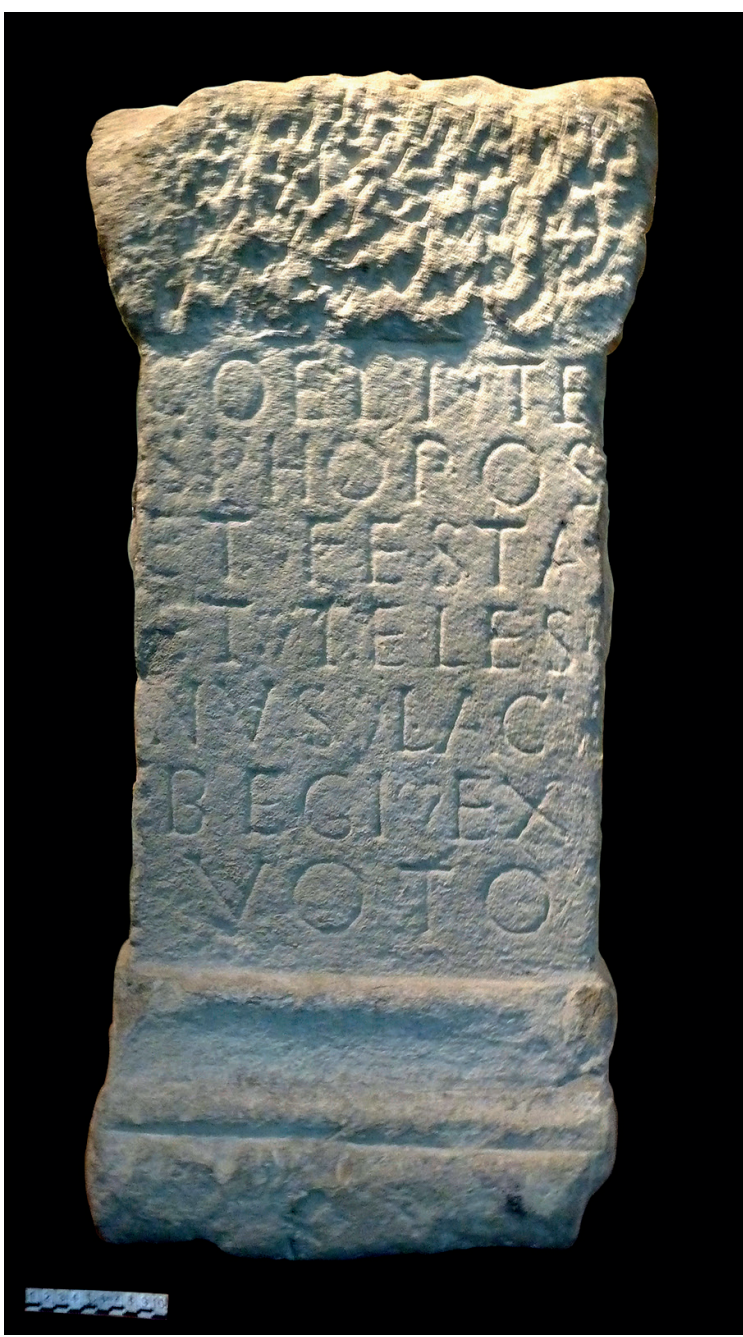

Figure 5

Votive for the Vasconian deity Lacubegis

(Museo de Navarra, Pamplona). M. Ramírez Sánchez

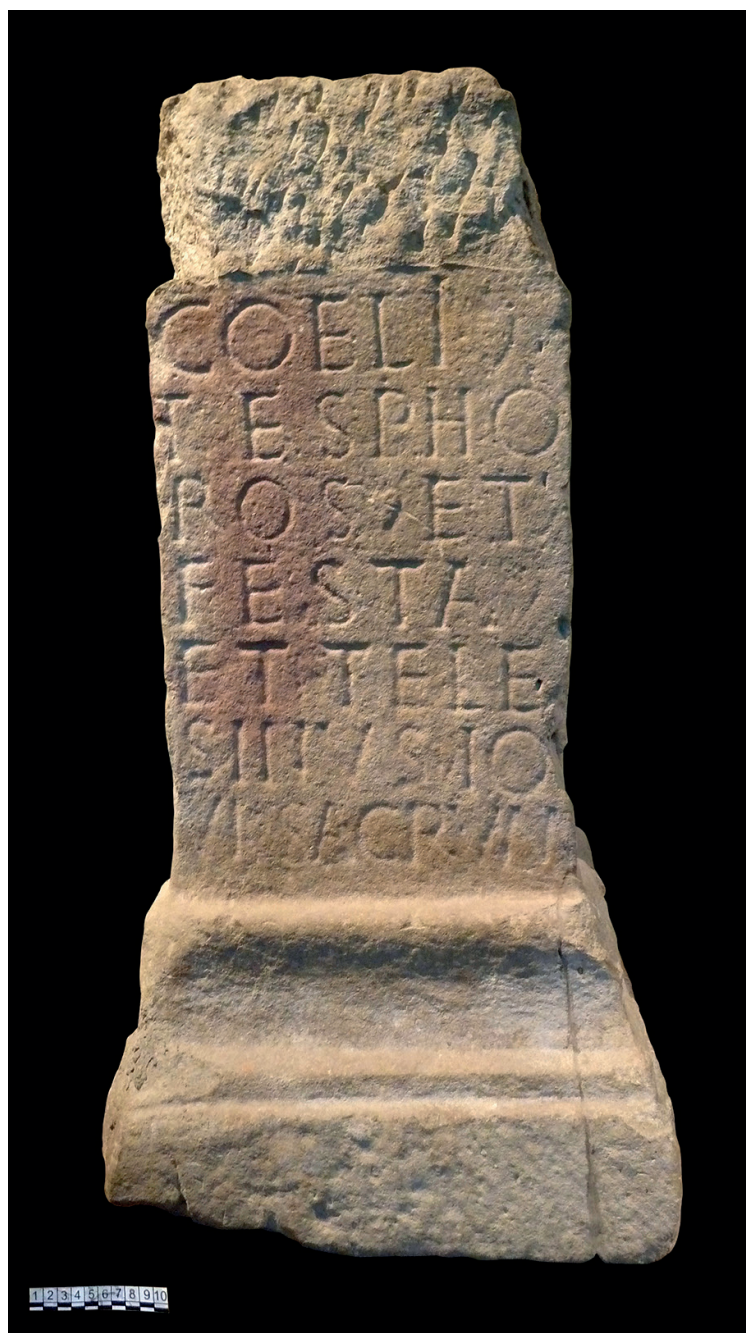

Figure 6

Votive for Iuppiter

(Museo de Navarra, Pamplona).

M. Ramírez Sánchez

47 AE 1930: 18; AE 1951: 280; ILER 54; IRMNa 17: Iovi O(ptimo)/M(aximo) L(ucius) Se/mpro/nius G/ eminus/l(ibens) p(ecunia) s(ua). (Escalada, 1927: 599f. w. Figure; Escalada, 1929: 190-192; Escalada, 1943: 126-130; Taracena; Vázquez de Parga, 1946: 441, No. 1, w. Figure I und II; Mezquíriz, 1956, 22 w. Figure; Gamer, 1974: 241, No. 21 w. Figure 54a-d; Gamer, 1989: 248, No. NA 1 w. Figure 41a-d; Velaza, 2011: 588 w. Figure 15). 


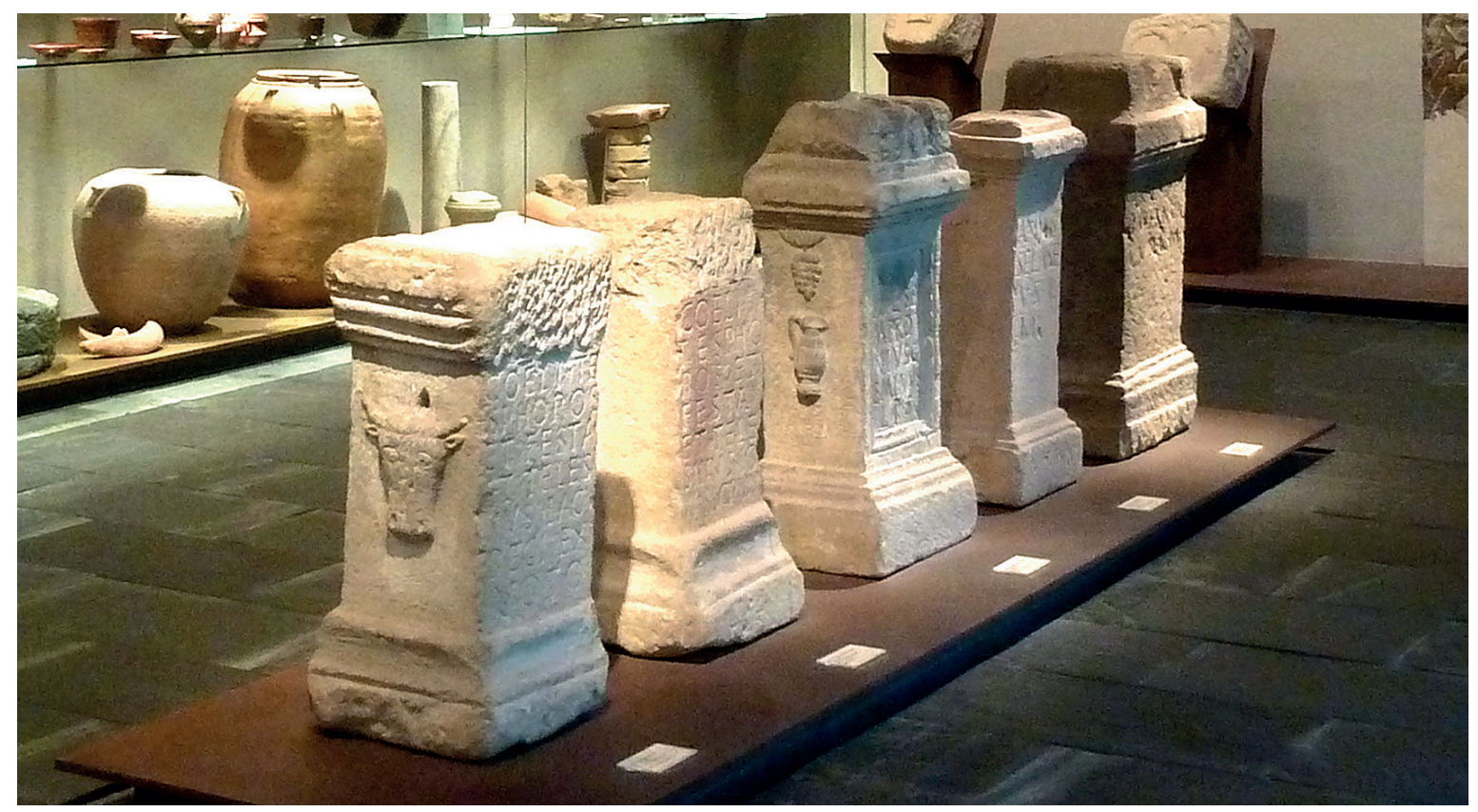

Figure 7

The two votives together with the bull protome on the side of the votive for Lacubegis

(Museo de Navarra, Pamplona). M. Ramírez Sánchez

A bull on the reverse of Tiberian coins in the Vasconian territory therefore could indicate, in my opinion, the preservation of local Vascon traditions by the Romans and also the friendly relationship between Vasconians and Romans. Iconographically, since the $4^{\text {th }}$ emission under Augustus a bull on the reverse is shown as early as the elevation of the city to municipium 26 BC. ${ }^{48}$

Thus, in the Early Principate the Vasconians appear in the numismatic evidence as a prime example of the Romanization process, as the iconography of the reverse can be interpreted both Roman and Vasconian in a religious sense; the legend on the reverse shows the integration of Calagurris as municipium, which underlines the importance of the city in a civic sense.

48 (García-Bellido; Blázquez, 2002: 222-225, No. 5-25 (emissions 4-20)). The iconography on the reverse seems to be a supraregional assumption from a Phoenician, Iberian and Celtiberian tradition, which is reinterpreted in the Vasconia as a local deity: (García-Bellido; Blázquez, 2002: 38-45, No. 2-6; 12-22 (Arse); 46-47, No. 1-6 (Asido); 68, No. 1 (Bora); 71-81, No. 19; 27; 50 (Caesaraugusta); 97-100, No. 13 (Carthago Nova); 111, No. 1-2 (Detumo); 114-119, No. 1-27 (Ebusus); 129-141, No. 8; 36?; 39 (Emporion); 142-143, No. 3-5; 8-9 (Ercavica); 155, No. 1-2 (Graccurris; Vasconian city and mint); 216-217, No. 5-6; 9 (Ituci); 219-220, No. 7-8 (Cascantum; probably Vasconian city); 227-233, No. 2; 9-10; 13; 16; 19-25; 32-35; 38; 43-48 (Castulo); 234, No. 2 (ke.l.i.n); 235-240, No. 19-24; 26-30; 35-37 (Celsa); 253-254, No. 4; 6; 8-9 (Clunia); 261, No. 1-2 (Lacipo); 284-286, No. 1-2; 9-10 (n.e.r.o.n.k.e.n); 290-295, No. 17-21; 33-35; 37-39 (Obulco); 304-305, No. 1-5 (Orippo); 353-355, No. 13 (Sexs); 362-365, No. 23 (Tarraco; Tiberian reign); 375-382, No. 41-43 (Turiaso; all in Tiberian reign); 388-396, No. 2-3; 18; 30; 33; 43; 45; 47; 64-65 (u.n.ti.ke.s.ke.n); 399, No. 2-3 (Osicerda); 403-404, No. 1-5 (Vesci)). (Gozalbes, 2020) with further details on the coin types and the emissions. 


\section{CONCLUSION}

The coin emission is significant for the reign of Tiberius. The obverse with the title of the emperor is to be seen in demonstrative differentiation to his predecessor Augustus, i.e. by avoiding the praenomen imperatoris, which propagates a new style of rule. ${ }^{49}$ However, the reverse is to be seen in continuity with Augustus, because here the focus is on the process of Romanization. This is evidenced by the duoviri and the reference to the municipium Calagurritanum on the reverse. Both refer to the new administrative structures in Hispania and both were implemented under Augustus in the early years of his principate with a reorganization of the two provinces Hispania ulterior and Hispania citerior since $27 \mathrm{BC}$. With the creation of at least 11 conventus iuridici and by awarding the status as colonia, municipia or civitas vetera, local residents could participate as high level officials in the Roman Empire. This was an important step not only towards a successful integration of the natives into the mechanisms of Roman Imperial rule, but also a main trigger for the process of Romanization, which began in the Julio-Claudian dynasty and reached its peak in the second century AD. ${ }^{50}$

With this coin emission Tiberius cleverly succeeds iconographically in depicting the Roman and the native Vasconian components in a religious and civic sense side by side $^{51}$, referring in turn to his predecessor, who founded cities in the Vasconia in order to propagate a friendly relationship between Romans and Vasconians. The reverse was struck already under Augustus, which strengthens the argument. ${ }^{52} \mathrm{Ca}$ lagurris was already allying itself with Caesar during the Civil War between Caesar and Pompey, ${ }^{53}$ therefore Tiberius might even refer back to the res publica with the reverse. The coin is an example of how Tiberius addresses both the Roman and the provincial populations and was able to illustrate his new style of rule - different from Augustus but with continuity - through the circulation of coins in Hispania and beyond. ${ }^{54}$ It is suggested, therefore, that the coins with these two duoviri are to be dated in the early years of the government of Tiberius. A further clue is the namesake of L. Fulvius Sparsus, the student of Latro, the latter of whom died around 4 BC. ${ }^{55}$

\footnotetext{
${ }^{49}$ It could be argued, however, that the exact title of the princeps in the province of Hispania was not widely known. However, coins with the praenomen imperatoris are already known under Augustus: (Hill, 1931: 178, 6).

${ }^{50}$ Further literature in note 32.

${ }^{51}$ It could be argued, however, that the coin was struck by two duoviri, but it can be assumed that this did not happen without the consent of the emperor: (Regling, 1933: 483-484; 489).

52 (García-Bellido; Blázquez, 2002: 222-225) with further literature. Here note 6.

53 Val. Max. 7,6,ext 3; (Klär, 2017: 87-91).

${ }^{54}$ On the circulation of coins: (Wolters, 2006; Frey-Kupper; Stannard, 2018).

${ }^{55}$ Hieron. Chron. 194,1.
} 


\section{BIBLIOGRAPHY}

$A E=$ L'Année Épigraphique. Revue des publications épigraphiques relatives à l'Antiquité romaine, Paris.

ALFÖLDI, A. (1953): Studien über Caesars Monarchie, Lund.

ALFÖLDY, G. (1969): Fasti Hispanienses: Senatorische Reichsbeamte und Offiziere in den spanischen Provinzen des Römischen Reiches von Augustus bis Diokletian, Wiesbaden.

ALFÖLDY, G. (2007): “Fasti und Verwaltung der hispanischen. Provinzen: Zum heutigen Stand der Forschung, R. Haensch; J. Heinrichs (ed.): Herrschen und Verwalten: Der Alltag der römischen Administration in der Hohen Kaiserzeit, 325-356. Köln.

ASSENMAKER, P. (2012): “Nouvelles perspectives sur le titre d'imperator et l'appellatio imperatoria sous la République", Revue belge de Philologie et d'Histoire n 90, 111-142, Brussels.

BADIAN, E. (1958): Foreign Clientelae (264-70 B.C.), Oxford.

BARCELÓ, P. (1995):"Zur Mentalität des antiken Stadtbewohners”, Die alte Stadt n 1, 51-64, Weinstadt.

BELTRÁN LLORIS, F. (2017): “Augusto y el valle medio del Ebro”, Gerion n 35, 525-540, Madrid.

BELTRÁN LLORIS, F.; VELAZA FRÍAS, J. (2009):“De etnias y monedas: Las 'cecas vasconas', una revision crítica", J. Andreu Pintado (ed.), Los Vascones de las fuentes antiguas: en torno a una etnia de la antigüedad peninsular, 99-126. Barcelona.

BÉRANGER, J. (1953): Recherches sur l'aspect idéologique du principat, Basel.

BERNECKER, A. (1980): Das Adoptionsdatum des Tiberius und die Nundinalschaltung: 26. oder 27.6. 4 n. Chr?, Bonn.

BLÁZQUEZ, J. M. (1962): Religiones primitivas de Hispania Vol. 1: Fuentes literarias y epigráficas, Madrid.

BLÁZQUEZ, J. M. (1975): Diccionario de religiones prerromanas de España.

BMC = Mattingly, H. (1965): Coins of the Roman Empire in the British Museum Vol. I: Augustus to Vitellius, London.

BORNECQUE, H. (1902 [repr. 1967]): Les déclamations et les déclamateurs d'après Sénèque le Père, Hildesheim.

BOTERMANN, H. (1992): "Rechtsstaat oder Diktatur: Cicero und Caesar 46-44 v. Chr.”, Klio $n^{\circ} 74,179-196$, Berlin.

BRUNT, P. A. (1971): Italian Manpower: 225 BC-AD 14, Oxford.

CAMPBELL, J. B. (1984): The Emperor and the Roman Army: 31 BC - AD 235, Oxford.

CANCIANI, F. (1997), “Zeus/Jupiter”, LIMC nº 8, 421-470, Zürich; Munich. 
CANTO, A. M. (1997): "La Tierra del Toro: Ensayo de identificación de ciudades vasconas", Archivo Español de Arqueología nº 70 (175-176), 31-70, Madrid.

COLLADO CENZANO, L.V. (2006): "La identidad de los Berones bajo la Romanización”, Berceo $n^{\circ} 150,91-114$, Logroño.

COMBÉS, R. (1966): Imperator: Recherches sur l'emploi et la signification du titre d'imperator dans la Rome républicaine, Paris.

COOK A. B. (1914 [repr. 1964]): Zeus: A study in Ancient Religion. Vol. 1: Zeus, God of the bright sky, Cambridge.

DAHLHEIM, W. (2005): Julius Caesar: Die Ehre des Kriegers und die Not des Staates, Paderborn.

DAHLHEIM, W. (2010): Augustus: Aufrührer, Herrscher, Heiland: Eine Biographie, Munich.

DEININGER, J. (1972): "Von der Republik zur Monarchie: Die Ursprünge der Herrschertitulatur des Prinzipats", Aufstieg und Niedergang der römischen Welt n 1.1, 982-997, Berlin; New York.

DOPICO CAÍNZOS, M. (1986): “Los conventus iuridici: Orígen, cronología y naturaleza histórica", Gerion n 4, 265-283, Madrid.

ECK, W. (2006): Augustus und seine Zeit, Munich.

ELORZA, J. C. (1972): “Religiones del país vasco-navarro en época romana”, Estudios de Deusto $n^{\circ} 20,357-366$, Bilbao.

ERRioja = ESPINOSA, U. (1986): Epigrafía Romana de La Rioja, Logroño.

ESCALADA, F. (1927): "Un monumento arqueológico del Castillo de Javier", Boletín de la Comisión de Monumentos de Navarra n³.1, 599-600, Pamplona.

ESCALADA, F. (1929):“Dos inscripciones romanas”, BRAH n 94, 190-192, Madrid.

ESCALADA, F. (1943): La arqueología en la Villa de Javier y sus contornos, Pamplona.

ESPINOSA, U. (1984): Calagurris Iulia, Logroño.

FABIA, P. (1909): “L'avènement officiel de Tibère: Examen du récit de Tacite (Annales 1, 11-13)", Revue de philologie, de littérature et d'histoire anciennes n 33, 28-58, Paris.

FAmit = DEGRASSI, A. (1963): Fasti Amiternini, Inscr. Ital XIII, 2, 185-200, Rome.

FLACH, D. (1973): “Der Regierungsanfang des Tiberius”, Historia n²2, 552-569, Stuttgart.

FLAIG, E. (1992): Den Kaiser herausfordern: Die Usurpation im Römischen Reich, Frankfurt am Main; New York.

FREY-KUPPER, S.; STANNARD, C. (2018):“Evidence for the Importation and Monetary Use of Blocks of Foreign and Obsolete Coins in the Ancient World", B. Woytek (ed.): Infrastructure and Distribution in Ancient Economies: Proceedings of a Conference held at the Austrian Academy of Sciences, 28-31 October 2014, 283-345, Vienna.

GALINSKY, K. (2012): Augustus: Introduction to the Life of an Emperor, Cambridge. 
GAMER, G. (1974):"Römische Altarformen im Bereich der Stelengruppen Burgos und Navarra", Madrider Mitteilungen n 15, 209-246, Madrid.

GAMER, G. (1989): Formen römischer Altäre auf der Iberischen Halbinsel, Mainz.

GARCÍA-BELLIDO, M. P. (1997): "Coinage and Ethnicity in Celtic Spain", Zeitschrift für celtische Philologie n 49-50, 219-242, Tübingen.

GARCÍA-BELLIDO, M. P. (2007):“El abastecimiento de moneda al ejército romano en el NO durante las guerras cántabras", Larouco n 4, 45-65, Sada, La Coruña.

GARCÍA-BELLIDO, M. P.; BLÁZQUEZ, C. (2002): Diccionario de cecas y pueblos hispánicos Vol. II: Catálogo de cecas y pueblos, Madrid.

GARDNER, J. F. (2009): “The Dictator”, M. Griffin (ed.), A Companion to Julius Caesar, 57-71, Malden, MA; Oxford.

GELZER, M. (1921 [repr. 1960]): Caesar: Der Politiker und Staatsmann, Wiesbaden.

GESCHE, H. (1976): Caesar, Darmstadt.

GIRARDET, K. M. (1996):“Politische Verantwortung im Ernstfall: Cicero, die Diktatur und der Diktator Caesar", C. Mueller-Goldingen; K. Sier (ed.); H. Becker: Lenaika: Festschrift für Carl Werner Müller zum 65. Geburtstag am 28. Januar 1996, 217-251, Stuttgart; Leipzig.

GOODYEAR, F. R. D. (1972): The Annals of Tacitus I: Annals 1, 1-54, Cambridge.

GOTTER, U. (2015): “Penelope's Web, Or: How to Become a Bad Emperor Post Mortem”, H. Börm (ed.): Antimonarchic Discourse in Antiquity, 215-233, Stuttgart.

GOZALBES, H. (2020): “La iconología del toro en la moneda provincial acuñada bajo el gobierno de Tiberio en el valle interior del Ebro", Cuadernos de Arqueología de la Universidad de Navarra $n^{\circ} 28,41-80$, Pamplona.

GRANT, M. (1946 [repr. 1969]): From Imperium to Auctoritas: A Historical Study of Aes Coinage in the Roman Empire 49 BC-AD 14, Northampton.

GRANT, M. (1950): Aspects of the Principate of Tiberius: Historical Comments on the Colonial Coinage issued outside Spain, New York.

GRENADE, P. (1961): Essai sur les origines du principat: Investiture et renouvellement des pouvoirs impériaux, Paris.

GUADÁN, A. M. de (1980): La moneda ibérica: Catálogo de numismática ibérica e ibero-romana, Madrid.

GÜNTHER, S. (2014): "(Nur) Erinnerung an die gute, alte Zeit? Zur Funktion des Divus Augustus in der Münzprägung der Frühen Kaiserzeit", Münzen Revue n 9, 57-61, Regenstauf.

HAMMOND, M. (1957): "Imperial Elements in the Formula of the Roman Emperors during the First Two and a Half Centuries of the Empire", Memoirs of the American Academy in Rome $n^{\circ}$ 25, 17-64, Rome. 
HAVENER, W. (2016): Imperator Augustus: Die diskursive Konstituierung der militärischen persona des ersten römischen princeps, Stuttgart.

HELM, R. (1953): “Porcius Latro”, Pauly-Wissowa n²2.1, 233-235, Stuttgart.

HEp/HEpOl = VELÁZQUEZ SORIANO, I. (1995ff.): Hispania Epigraphica, Madrid.

HERNÁNDEZ GUERRA, L. (1997): “Datos para el estudio de la sociedad y religión en la epigrafía de Navarra", Memorias de Historia antigua n¹8, 169-193, Oviedo.

HERNÁNDEZVERA, J. A.; NUÑEZ MARCÉN, J.; MARTÍNEZTORRECILLA, J. M. (2005):“La Romanización", J. A. Hernández Vera; J. G., Moya Valgañón; B. Arrúe Ugarte (ed.): Historia del arte en La Rioja Vol. 1: De la Prehistoria a la Antigüedad Tardia, 101-166, Logroño.

HILL, G. G. (1931): Notes on the Ancient Coinage of Hispania Citerior, New York.

HOHL, E. (1933): “Wann hat Tiberius das Prinzipat übernommen?”, Hermes n 68, 106-115, Stuttgart.

HORSTER, M. (2000): Bauinschriften römischer Kaiser: Untersuchungen zur Inschriftenpraxis und Bautätigkeit in Städten des westlichen Imperium Romanum in der Zeit des Prinzipats, Stuttgart.

HUARTE LERGA, J.V. (1997):"Lacubegi eta Lacubeli”, Fontes lingua vasconum. Studia et documenta $\mathrm{n}^{\circ} 76,361-368$, Pamplona.

HÜBNER, E. (1893): Monumenta Linguae Ibericae adiecta est tabula geographica, Berlin.

IAph = REYNOLDS, J.; ROUECHÉ C.; BODARD, G. (2007): Inscriptions of Aphrodisias, London.

IGUÁCEL DE LA CRUZ, P. (2007): "El Sequeral: Un nuevo tramo de la muralla romana de Calagurris Iulia", Caesaraugusta n 78, 425-436, Zaragoza.

ILER = VIVES, J. (1972): Inscripciones latinas de la España romana, Barcelona.

ILS = DESSAU, H. (31962): Inscriptiones Latinae Selectae, Berlin.

IRABURU, J. M. (1975): "Notas sobre varias piedras de Navarra", Cuadernos de etnología y etnografía de Navarra n 7, 83-91, Pamplona.

IRMNa = CASTILLO, C.; GOMEZ-PANTOJA, J.; DOLORES MAULEÓN, M. (1981): Inscripciones Romanas del Museo de Navarra, Pamplona.

JEHNE, M. (1987): Der Staat des Dictators Caesar, Köln.

JEHNE, M. (1997): Caesar, München.

KAMPFF, G. (1963): "Three Meetings of the Senate in the Early Principate", Phoenix n 17, 25-58, Toronto.

KIENAST, D. (1961): "Imperator", Zeitschrift der Savigny-Stiftung für Rechtsgeschichte n 78, 403-421, Vienna.

KIENAST, D. (2009): Augustus: Prinzeps und Monarch, Darmstadt.

KIENAST, D.; ECK, W.; HEIL, M. (2017): Römische Kaisertabelle: Grundzüge einer römischen. Kaiserchronologie, Darmstadt. 
KLÄR, T. (2017): Die Vasconen und das Römische Reich: Der Romanisierungsprozess im Norden der Iberischen Halbinsel, Stuttgart.

KLINGNER, F. (1954): “Tacitus über Augustus und Tiberius: Interpretationen zum Eingang der Annalen", Sitzungsberichte der Bayrischen Akademie der Wissenschaften n 7, 26-37, Munich [repr. KLINGNER, F. (1964): Studien zur griechischen und römischen Literatur, 624-658, Zürich; Stuttgart].

KRAFT, K. (1952/1953): “Der goldene Kranz Caesars und der Kampf um die Entlarvung des, Tyrannen'.", Jahrbuch für Numismatik und Geldgeschichte n 3/4, 7-97, Munich.

KROYMANN, J. (1970):“Cicero und Sallust über den Neubau des Staates unter Caesars Diktatur", M. von Albrecht (ed.): Silvae: Festschrift für Ernst Zinn zum 60. Geburtstag dargebracht von Kollegen, Schülern und Mitarbeitern, 107-124, Tübingen.

LE ROUX, P. (2004):“La question des conventus dans la péninsule Ibérique d'époque romaine", C. Auliard; L. Bodiou (ed.): Au jardins des Hespérides: Histoire, societé et épigraphique des mondes anciens: Mélanges offerts à Alain Tranoy, 337-356, Rennes.

LESUISSE, L. (1961): “La nomination de l'empereur et le titre d"imperator'”, L'Antiquité Classique $\mathrm{n}^{\circ}$ 30, 415-428, Liège.

LEVICK, B. (1976): Tiberius the Politician, London.

LEVICK, B. (2010): Augustus. Image and Substance, Harlow; Munich.

MCFAYDEN, D. (1920): The History of the Title Imperator under the Roman Empire, Chicago.

MEIER, C. (1980): Die Ohnmacht des allmächtigen Dictators Caesar: Drei biographische Skizzen, Frankfurt am Main.

MEIER, C. (1982): Caesar, Berlin.

MEIER, M. (2014): Caesar und das Problem der Monarchie in Rom, Heidelberg.

MEZQUÍRIZ, M. Á. (1956): Guiá del Museo de Navarra, Pamplona.

MORGAN, L. (1997): “'Levi quidem de re...' Julius Caesar as Tyrant and Pedant", Journal of Roman Studies $n^{\circ} 87,23-40$, London.

MÜNSCHER, K. (1910):“Fulvius [109]”, Pauly-Wissowa n 7.1, 279-280, Stuttgart.

ORTIZ DE URBINA, E. (1995): "Die römische municipale Ordnung. Realität und Virtualität”, Bonner Jahrbücher n 195, 39-66, Mainz.

PASCUAL MAYORAL, P.; PASCUAL GONZÁLEZ, H. (1984): Carta arqueológica de La Rioja Vol. 1: El Cidacos, Logroño.

PIPPIDI, D. M. (1944): Autour de Tibère, Bucharest.

REGLING, K. (1933):“Münzwesen”, Pauly-Wissowa n 16.1, 458-491.

ROSENBLITT, J. A. (2019): Rome after Sulla, London; New York. 
RPC = BURNETT, A.; AMANDRY, M.; RIPOLLÈS, P. P. (1992): Roman Provincial Coinage Vol. I: From the Death of Caesar to the Death of Vitellius (44 BC-AD 69), London; Paris.

RIPOLLÈS, P. P. (2010): Las acuñaciones provinciales romanas de Hispania, Madrid.

RUIZ TRAPERO, M. (1968): Las acuñaciones hispano-romanas de Calagurris: Su ordenación cronologíca y su trascendencia histórica, Barcelona.

SCHEID, J.; Broise, H. (1980): “Deux nouveaux fragment des actes des frères arvales de l'année 38 ap. J.-C.", Mélanges d'archéologie et d'histoire de l'École française de Rome n 92.1, 215-248, Rome.

SAGE, M. M. (1982/1983): "Tacitus and the Accession of Tiberius", Ancient Society n 13/14: 293-321, Leuven.

SCHMITT, H. H. (1958):“Der pannonische Aufstand des Jahres 14 n. Chr. und der Regierungsantritt des Tiberius", Historia n 7, 378-383, Stuttgart.

SCHRÖMBGES, P. (1986): Tiberius und die Res Publica Romana: Untersuchungen zur Institutionalisierung des frühen römischen Principats, Bonn: Habelt.

SCHUMACHER, L. (1985): “Die imperatorischen Akklamationen der Triumvirn und die auspicia des Augustus", Historia n 34, 191-222, Stuttgart.

SIGMUND, C. (2014): "Königtum" in der politischen Kultur des spätrepublikanischen Rom, Berlin; Boston.

SNG Copenhagen = JENKINS, G. K.; KROMANN, A. (1979): Sylloge Nummorum Graecorum: The Royal Collection of Coins and Medals, Danish National Museum Vol. 43: Spain-Gaul, Copenhagen.

SOLIN, H. (1982a): Die griechischen Personennamen in Rom: Ein Namenbuch. Vol. 1, Berlin; New York.

SOLIN, H. (1982b): Die griechischen Personennamen in Rom: Ein Namenbuch, Vol. 2, Berlin.

STÄCKER, J. (2003): Princeps und Miles: Studien zum Bindungs- und Nahverhältnis von Kaiser und Soldat im 1. und 2. Jahrhundert n. Chr., Hildesheim; Zürich; New York.

STEVENSON, T. (2015): Julius Caesar and the Transformation of the Roman Republic, London; New York.

SYDENHAM, E. A. (1952 [repr. 1976]): The Coinage of the Roman Republic, New York.

Syll. ${ }^{3}=$ HILLER VON GAERTRINGEN, F. ( ${ }^{3} 1915-24$ [repr. 1960]): Sylloge inscriptionum Graecarum 4 Vols, Hildesheim.

SYME, R. (1958a): "Emperor Caesar: A Study in Nomenclature”, Historia n 7, 172-188, Stuttgart [repr. SYME, R. (1979): Roman Papers Vol. I. Oxford, 361-377].

SYME, R. (1958b): Tacitus Vol. 2, Oxford.

TARACENA, B.;VÁZQUEZ DE PARGA, L. (1946): "Excavaciones en Navarra V: La Romanización”, Príncipe de Viana n 7.24, 413-470, Pamplona. 
TIMPE, D. (1962): Untersuchungen zur Kontinuität des frühen Prinzipats, Wiesbaden.

URANGA, J. E. (1966): “El culto al toro en Navarra y Aragón”, J. Maluquer de Motes (ed.): Problemas de la prehistoria y de la etnologia vascas: IV Symposium de Prehistoria peninsular, 223-231, Pamplona.

VELAZA, J. ( 1995): "Epigrafía y dominios lingüísticos en el territorio de los Vascones", F. Beltran Lloris (ed.): Roma y el nacimiento de la cultura epigráfica en Occidente: Actas del Coloquio Roma y las primeras culturas epigráficas del Occidente Mediterráneo (siglos II. a. C.-I. d. C.) (Zaragoza, 4 a 6 noviembre de 1992), 209-218, Zaragoza.

VELAZA, J. (2011): “Interpretatio romana, interpretatio vasconica: Modelos y expresiones de la interpretación religiosa en la epigrafía del territorio de los vascones", J. Cardim Ribeiro (ed.): Diis deabusque. Actas do II Colóquio Internacional de Epigrafia "Culto e Sociedade", Sintra, 16-18/03/1995, 573-594, São Miguel de Odrinhas.

VITTINGHOFF, F. (1951): Römische Kolonisation und Bürgerrechtspolitik unter Caesar und Augustus, Mainz.

VIVES, A. (1924): La moneda hispánica Vol. IV, Madrid.

WELLESLEY, K. (1967): “The Dies Imperii of Tiberius", Journal of Roman Studies n57, 23-30, London.

WELWEI K.-W. (1996): "Caesars Diktatur, der Prinzipat des Augustus und die Fiktion der historischen Notwendigkeit", Gymnasium n²103, 477-497, Heidelberg.

WIEGELS, R. (1985): Die Tribusinschriften des römischen Hispanien: Ein Katalog, Berlin.

WILL, W. (1992): Julius Caesar: Eine Bilanz, Stuttgart.

WILL, W. (2009): Caesar, Darmstadt.

WOLTERS, R. (2006): "Geldverkehr, Geldtransporte und Geldbuchungen in römischer Republik und Kaiserzeit: Das Zeugnis der schriftlichen Quellen", Belgisch tijdschrift voor numismatiek en zegelkunde (Revue belge de numismatique et de sigillographie) n 152, 23-49, Brussels. 